\title{
SEEDLING GROWTH OF TREE SPECIES UNDER DOSES OF HYDROGEL AND TWO LEVELS OF LUMINOSITY ${ }^{1}$
}

\author{
Roberto Albuquerque Pontes Filho ${ }^{2 *}$, Franklin Aragão Gondim² and Mirian Cristina Gomes Costa ${ }^{3}$
}

\footnotetext{
${ }^{1}$ Received on 28.08.2017 accepted for publication on 19.03.2018.

${ }^{2}$ Instituto Federal do Ceará- Reitoria, Campus Maracanau, CE - Brasil. E-mail: <roberto.consultorambiental10@gmail.com> and<aragao@ifce.edu.br>.

${ }^{3}$ Universidade Federal do Ceará, Centro de Ciências Agrárias, Fortaleza, CE - Brasil. E-mail: <mirian.costa@ufc.br>.

*Corresponding author.
}

\begin{abstract}
Hydrogels (polyacrylamide compounds) are recommended in agriculture and forestry as soil conditioners because they are able to absorb water and increase its stocks in the soil. The aim of this study was to determine the most suitable dose of hydrogel to establish seedlings of Enterolobium contortisilliquum (Vell.) Morong under two levels of luminosity. Seedlings of Enterolobium contortisilliquum (Vell.) Morong were planted in pots, following a design of subdivided plots, consisting of two levels of luminosity in the plots: full sun and 50\% luminosity, and 10 doses of hydrogel in the sub-plots: $0.0,2.0,2.5,3.0,3.5,4.0$, $4.5,5.0,5.5$ and $6.0 \mathrm{~g} \mathrm{~L}^{-1}$. Seventy-two days after the seedlings were transplanted to the pots, plant height and diameter were determined, together with the height to diameter ratio, root length and diameter, shoot and root dry weight, and the shoot to root ratio. The lowest ratios between height and stem diameter $(8.50$ and 8.68) occurred in the seedlings in full sun at the doses of 0 and $2 \mathrm{~g}$ hydrogel $\mathrm{L}^{-1}$ respectively. For shaded seedlings the lowest ratio (8.14) occurred at the dose of $3.0 \mathrm{~g} \mathrm{~L}^{-1}$, but with a lower coefficient of determination $\left(\mathrm{R}^{2}=0.68\right)$. Shoot dry weight increased with the dose of $2 \mathrm{~g} \mathrm{~L}^{-1}$ in full sun, and $3.5 \mathrm{~g} \mathrm{~L}^{-1}$ under shaded conditions. The doses of hydrogel giving the best initial development in seedlings under evaluation were $2 \mathrm{~g} \mathrm{~L}^{-1}$ in full sun and $3.5 \mathrm{~g} \mathrm{~L}^{-1}$ in the shaded environment. Although a response by the species to the doses of hydrogel was found, the benefits of the polymer were not evident under the conditions of the present study.
\end{abstract}

Keywords: Reforestation strategy; Polymers; Semi-arid conditions.

\section{CRESCIMENTO DE MUDAS DE ESPÉCIE ARBÓREA SOB DOSES DE HIDROGEL E DOIS NÍVEIS DE LUMINOSIDADE}

\begin{abstract}
RESUMO - Hidrogéis (compostos de poliacrilamida) têm sido recomendados na agricultura e na área florestal como condicionadores de solo, pois conseguem absorver água e aumentar seu estoque no solo. O objetivo deste estudo foi determinar a dose mais adequada de hidrogel para estabelecimento de mudas de Enterolobium contortisilliquum (Vell.) Morong em dois níveis de luminosidade. Mudas de Enterolobium contortisilliquum (Vell.) Morong foram plantadas em vasos, com delineamento em parcelas subdivididas, compreendendo dois níveis de luminosidade nas parcelas - pleno sol e 50\% de luminosidade, e dez doses de hidrogel nas subparcelas: 0,$0 ; 2,0 ; 2,5 ; 3,0 ; 3,5 ; 4,0 ; 4,5 ; 5,0 ; 5.5$ and 6,0 $\mathrm{g} \mathrm{L}^{-1}$. Aos 72 dias após o transplantio das mudas para os vasos, a altura e o diâmetro das plantas foram determinados, bem como a relação entre altura e diâmetro, comprimento e diâmetro das raízes, massa seca de parte aérea e raízes e a relação da massa de parte aérea e raizes. As menores relações entre altura e diâmetro do colo $(8,50$ e 8,68$)$ ocorreram para mudas a pleno sol com as doses 0 e $2 \mathrm{~g} \mathrm{~L}^{-1}$ de hidrogel, respectivamente. Para mudas sombreadas a menor relação $(8,14)$ ocorreu na dose 3, $0 \mathrm{~g} \mathrm{~L}^{-1}$, mas com menor coeficiente de determinação $\left(R^{2}=0,68\right)$. A massa seca de parte aérea aumentou a partir das doses $2 \mathrm{~g} \mathrm{~L}^{-1}$ a pleno sol e $3.5 \mathrm{~g} \mathrm{~L}^{-1}$ em condições sombreadas. As doses de hidrogel que proporcionaram melhor desenvolvimento inicial das mudas da espécie avaliada foram $2 \mathrm{~g} L^{-1}$ a pleno sol e $3.5 \mathrm{~g} \mathrm{~L}^{-1}$ em ambiente sombreado. Mesmo tendo sido constatada resposta da espécie às doses de hidrogel, os beneficios do polímero não ficaram evidentes nas condições em que foi realizado o presente estudo.
\end{abstract}

Palavras-Chave: Estratégia para reflorestamento; Polímeros; Condições semiáridas. 


\section{INTRODUCTION}

Degraded areas are distinctive as environments where the original characteristics have been modified beyond the limit for natural recovery (Noffs et al., 2000; Figueiredo et al., 2012). Such areas present innumerable limitations that usually make forestry activity inviable. Among these limitations should be mentioned a decrease in soil organic matter (OM) (Torres et al., 2006; Du Preez et al., 2011) and water deficiency, which is mainly limiting in arid and semi-arid zones.

Due to the temporal variability of the precipitation, and the reduced rainy season, soils in semi-arid zones present problems of water availability, hindering revegetation (Ochoa et al., 2016). Given this situation, various strategies have emerged for improving the availability of water in these degraded soils, such as the use of chemical conditioners, including polymers.

Polymers are macromolecules formed from smaller structural units (monomers) that undergo polymerisation reactions. Currently, polymers composed of polyacrylamide, and known as hydrogels, are used as soil conditioners in agriculture (Souza et al., 2016) and forestry (Vicente et al., 2015), as they are able to absorb water up to hundreds of times their own dry weight (Hennink and van Nostrum, 2012), favouring water storage in the soil (Koupai et al., 2008).

Precisely due to this characteristic, the use of hydrogels in recovery projects of degraded areas has been well investigated, as hydrogels can more effectively retain rainwater and make it available for longer periods (Fajardo et al., 2013), thereby increasing the chances of seedling survival, especially in recovery projects of degraded areas, where irrigation is impracticable.

Despite this, little is known about the most suitable dose of hydrogel for native semi-arid species. There are also no reports of whether plants being grown in a protected environment or in full sun changes the recommended dose of hydrogel. Another question is whether hydrogel can reduce or increase the effects of water stress in plants that have tuberous roots, as in the case of Enterolobium contortisilliquum (Vell.) Morong (Barreto and Ferreira, 2011). It should be noted however, that high doses of hydrogel can cause root strangulation (Mendonça et al., 2013).

The aim of this study was to determine the most suitable dose of hydrogel for the establishment of Enterolobium contortisilliquum (Vell.) Morong grown under full sun and under $50 \%$ shade, and to evaluate whether the addition of hydrogel to the soil reduces the effects of water stress in this species.

\section{MATERIALAND METHODS}

The study was carried out during August 2013 on the Maracanaú Campus of the Federal Institute of Science, Education and Technology of Ceará, at Maracanaú, in the State of Ceará, Brazil (3² $72^{\prime} \mathrm{S}$ and $\left.38^{\circ} 61^{\prime} \mathrm{W}\right)$. According to the Köppen classification, the local climate is type Aw (Funceme, 2014).

A completely randomised split-plot experimental design was used, consisting of two light environments (full sun and a 50\% reduction in luminosity) in the main plots, and ten doses of hydrogel $(0,2.0,2.5,3.0$, $3.5,4.0,4.5,5.0,5.5$ and $\left.6.0 \mathrm{~g} \mathrm{~L}^{-1}\right)$ in the sub-plots. Three replications were used, resulting in 60 experimental units.

The species used in the experiment was Enterolobium contortisilliquum (Vell.) Morong. This is a deciduous, heliophilic species and a selective hygrophyte (Lorenzi, 1998), which is considered a pioneer species (Lima et al., 2010). It is regarded as suitable

Table 1 - Chemical and granulometric properties of the soil used in the experiment. Tabela 1 - Propriedades químicas e granulométricas do solo usado no experimento.

\begin{tabular}{|c|c|c|c|c|c|c|c|c|c|c|}
\hline$\overline{\mathrm{pH}}$ & $\mathrm{Ca}^{2+}$ & $\mathrm{Mg}^{2+}$ & $\mathrm{K}^{+}$ & $\mathrm{Na}^{+}$ & \multirow{2}{*}{$\begin{array}{c}\mathrm{H}^{+}+\mathrm{Al}^{3+} \\
\mathrm{cmol}_{\mathrm{c}} \mathrm{kg}^{-1} \\
1.98\end{array}$} & $\mathrm{Al}^{3+}$ & SB & $\mathrm{CEC}$ & $\mathrm{V}$ & $\overline{\mathrm{P}}$ \\
\hline $\begin{array}{l}\text { (water) } \\
4.87\end{array}$ & 0.50 & 0.30 & 0.14 & 0.07 & & 0.85 & 1.01 & 3.00 & $\begin{array}{c}\% \\
33.80\end{array}$ & $\begin{array}{r}\mathrm{mg} \mathrm{kg}^{-1} \\
2.0\end{array}$ \\
\hline MO & \multicolumn{8}{|c|}{ Granulometric Composition $\left(\mathrm{g} \mathrm{kg}^{-1}\right)$} & \multicolumn{2}{|c|}{ Textural Class } \\
\hline $\mathrm{g} \mathrm{kg}^{-1}$ & & & Sand & & Silt & & Clay & & & ddy loam \\
\hline
\end{tabular}

Revista Árvore. 2018;42(1):e420112 
for the reforestation of degraded areas due to its rapid initial growth (Araújo and Paiva Sobrinho, 2011).

Seedlings of Enterolobium contortisilliquum (Vell.) Morong were grown in polypropylene bags. When the plants reached between 30 and $40 \mathrm{~cm}$ in height, they were replanted into pots with a capacity of 24 $\mathrm{kg}$ that made up the experimental units. The pots were filled with soil of a sandy loam texture, collected at a depth of $30 \mathrm{~cm}$ to avoid the presence of weeds. The chemical and granulometric properties of the soil used in the experiment are shown in Table 1.

Before replanting the seedlings, hydration of the hydrogel was carried out in one litre of distilled water for each of the three replications corresponding to each dose of hydrogel (0.0, 2.0, 2.5, 3.0, 3.5, 4.0, 4.5, $5.0,5.5$ and $\left.6.0 \mathrm{~g} \mathrm{~L}^{-1}\right)$. The polymer used was a potassium polyacrylamide from the FORTH Gel ${ }^{\circledR}$ Company. The dose of $0 \mathrm{~g} \mathrm{~L}^{-1}$ contained only distilled water.

When replanting, a sufficient volume of soil was removed from the centre of the pots to make room for the seedlings, and the hydrogel applied to the pots where the soil was removed. Half of the pots (30 units) were then placed in the environment under full winter sun and the other half in the environment with a 50\% reduction in luminosity (shaded area).

The area under full sun characterised the direct exposure of the plants to the environment, where the average temperature and relative humidity during the experimental period were $33.4^{\circ} \mathrm{C}$ and $50.1 \%$ respectively (Funceme, 2014).

The plants under $50 \%$ shade were distributed under a Sombrite screen. Temperature and relative humidity were monitored during the experiment by a Data Logger thermo-hygrometer with external sensor and a TFA Model 3030.15.0.00 PC connection; mean values were respectively $32.1^{\circ} \mathrm{C}$ and $52 \%$.

After replanting, the seedlings were irrigated for forty days with plain water, at an irrigation interval of five days, with a volume of water corresponding to $60 \%$ of soil capacity, i.e. $0.75 \mathrm{~L}$ of water per pot. Following this period, irrigation was stopped, with the plants remaining under a water deficit until the first loss of leaves, which occurred 72 days after replanting.

At 72 days after replanting (32 days after irrigation was suspended), plant height was measured from the soil surface to the apex of the plants with a ruler graduated in centimetres $(\mathrm{cm})$. The diameter of the stem was then measured using a digital calliper. The ratio between height and stem diameter was calculated.

At the end of the experiment in October 2013, each plant was harvested and separated into shoots and roots (Figure 1), with root length and diameter being determined by ruler and calliper, respectively. After these evaluations, the plants were placed in a forced air circulation oven at $65^{\circ} \mathrm{C}$ to constant weight, and then used to determine shoot dry matter (SDM) and root dry matter (RDM). The SDM to RDM ratio was calculated.

Analysis of variance (ANOVA) was initially carried out for all the variables under evaluation, and the normality of the data groups was checked by means of the KolmogorovSmirnov normality test. Normal and significant data by Ftest were submitted to Tukey's test to compare mean values in the qualitative treatments, and to regression analysis in the quantitative treatments, using the Sisvar 5.3 statistical software (Ferreira, 2011). In the regression analysis, the equations that best fit the data were selected based on the significance found by the F-test, with the regression coefficients tested at $1 \%$ or $5 \%$ probability by t-test, and based on the highest coefficient of determination $\left(\mathrm{R}^{2}\right)$.

\section{RESULTS}

The coefficients of determination were close to 1.0 for most of the attributes under evaluation. However, lower values for the coefficient of determination were

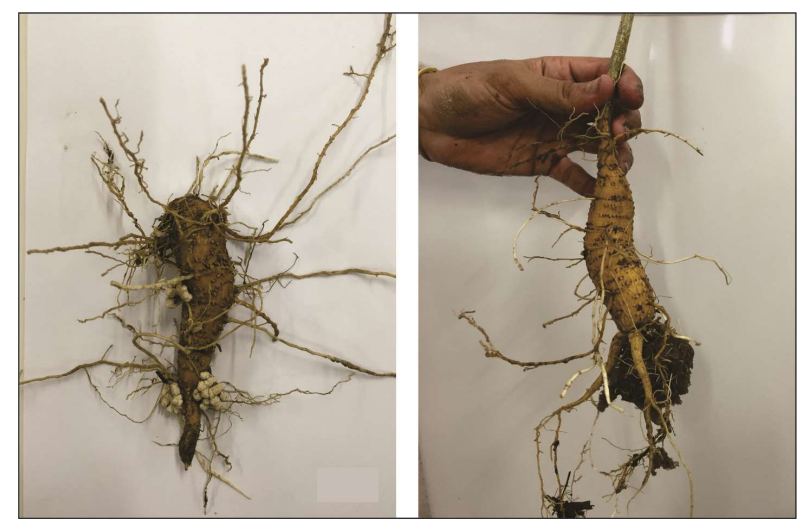

Figure 1 - Tuberous root of the Enterolobium contortisilliquum (Vell.) Morong seedling, root with no hydrogel (A) and with hydrogel (B) at 72 days.

Figura 1 - Raizes tuberosas de mudas de Enterolobium contortisilliquum (Vell.) Morong, raiz sem hidrogel (A) e com hidrogel (B) aos 72 dias.

Revista Árvore. 2018;42(1):e420112 
seen for the ratio between height and stem diameter in the shaded environment $\left(\mathrm{R}^{2}=0.68\right)$, and for the SDM to $\mathrm{RDM}$ ratio $\left(\mathrm{R}^{2}=0.48\right)$ and root diameter $\left(\mathrm{R}^{2}=0.44\right)$, both in full sun.

Based on the height and stem diameter of the Enterolobium contortisilliquum (Vell.) Morong (Figures $2 \mathrm{~A}$ and $2 \mathrm{~B}$ ), the data showed that at the lowest dose of hydrogel $\left(2.0 \mathrm{~g} \mathrm{~L}^{-1}\right)$ there was no difference for the two levels of luminosity compared to the control. For height (Figure 2A), it can be seen that starting from the $3.0 \mathrm{~g} \mathrm{~L}^{-1}$ dose of hydrogel, plants grown in the shaded environment had estimated heights that were significantly greater than the plants grown in full sun, this difference being equal to $29.1 \mathrm{~cm}$ (between the doses of 3.0 and $6.0 \mathrm{~g}$ hydrogel $\left.\mathrm{L}^{-1}\right)$.

It was possible to see an increase in height in the shaded seedlings at the dose of $5 \mathrm{~g}$ hydrogel $\mathrm{L}^{-}$ ${ }^{1}$ (Figure 2A); however, this increase was seen at a lower dose $\left(3.5 \mathrm{~g} \mathrm{~L}^{-1}\right)$ in the seedlings grown in full sun. The curve for stem diameter (Figure 2B) reached maximum point at the dose of $4.5 \mathrm{~g} \mathrm{~L}^{-1}$, where there was no difference between the plants that developed in the shaded environment or those in full sun. The ratio between height and stem diameter was smaller for the seedlings in full sun at doses of 0 and $2.0 \mathrm{~g}$ hydrogel L-1 (Figure 2C). This situation was reversed from the dose of $3 \mathrm{~g} \mathrm{~L}^{-1}$, when the seedlings under shaded conditions started to present the smallest ratio between height and stem diameter (Figure 2C).

An analysis of the data for shoot dry matter (SDM) (Figure 3A), showed that the value was lowest for seedlings developed in full sun at the dose of $0 \mathrm{~g}$ hydrogel $\mathrm{L}^{-1}$. However, at the dose of $2 \mathrm{~g} \mathrm{~L}^{-1}$ there was an increase in SDM, which was more pronounced for seedlings developed in full sun, so that the production of shoot biomass in those seedlings was the same as in the plants grown in the shaded environment. At the dose of $3.5 \mathrm{~g} \mathrm{~L}^{-1}$, the shaded seedlings showed an increase in shoot biomass production, again differing from the seedlings developed in full sun.

In the case of root dry matter (RDM) (Figure 3B), there was no difference between environments for most of the doses of hydrogel under evaluation. There was an increase in root dry matter production at the dose of $3 \mathrm{~g}$ hydrogel $\mathrm{L}^{-1}$ under both light conditions. The SDM to RDM ratio (Figure 3C) was lower for the plants developed in full sun than for plants developed in the

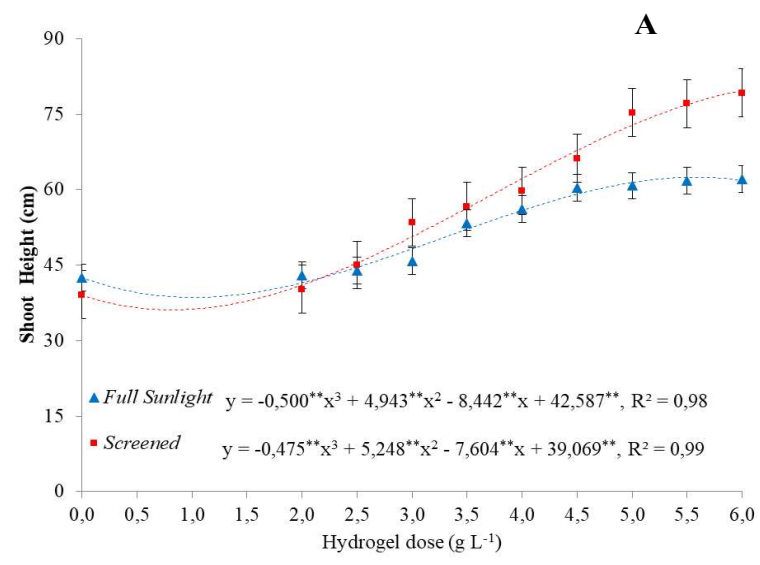

B

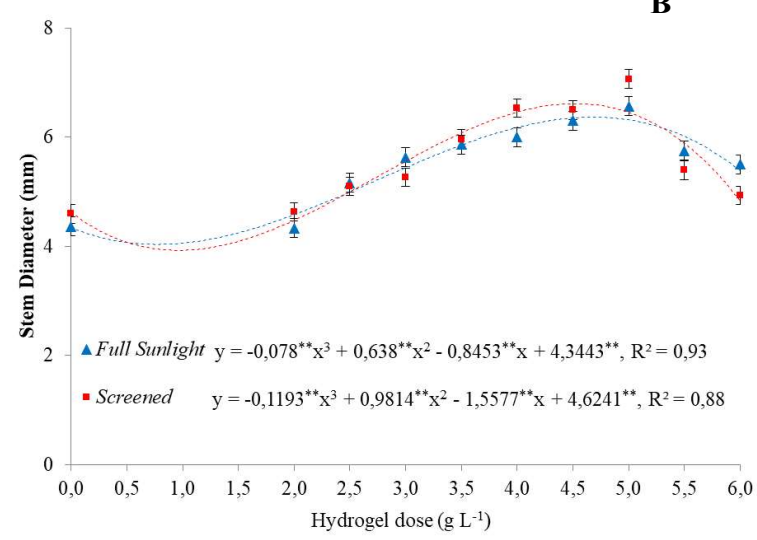

C

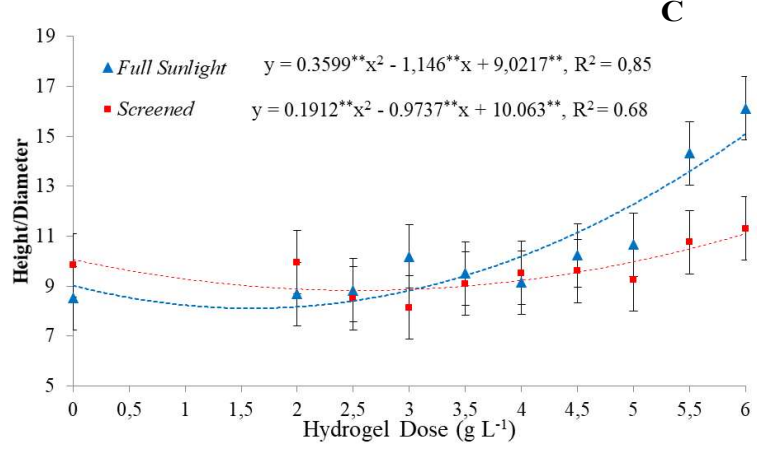

Figure 2 - Data for height (A), stem diameter (B), and height to stem diameter ratio (C) in plants of Enterolobium contortisilliquum (Vell.) Morong for hydrogel dose and different light environments (full sun and shaded).

Figura 2-Dados para altura (A), diâmetro do caule (B) e relação altura/diâmetro do caule $(C)$ em plantas de Enterolobium contortisilliquum (Vell.) Morong para doses de hydrogel e diferentes luminosidades (pleno sol e telado).

Revista Árvore. 2018;42(1):e420112 


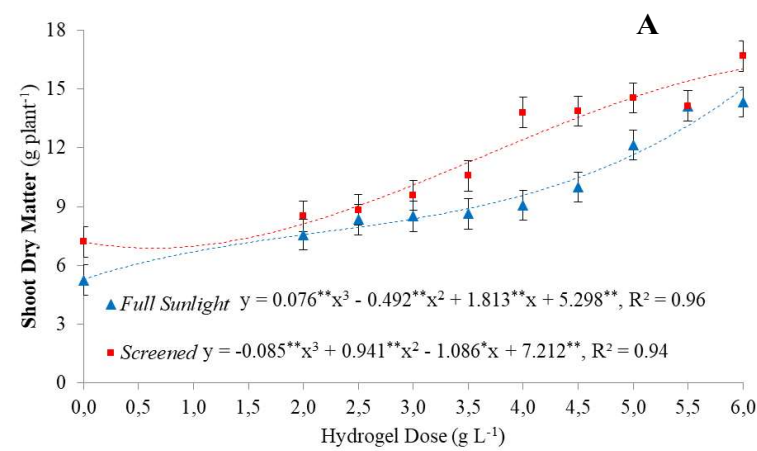

B
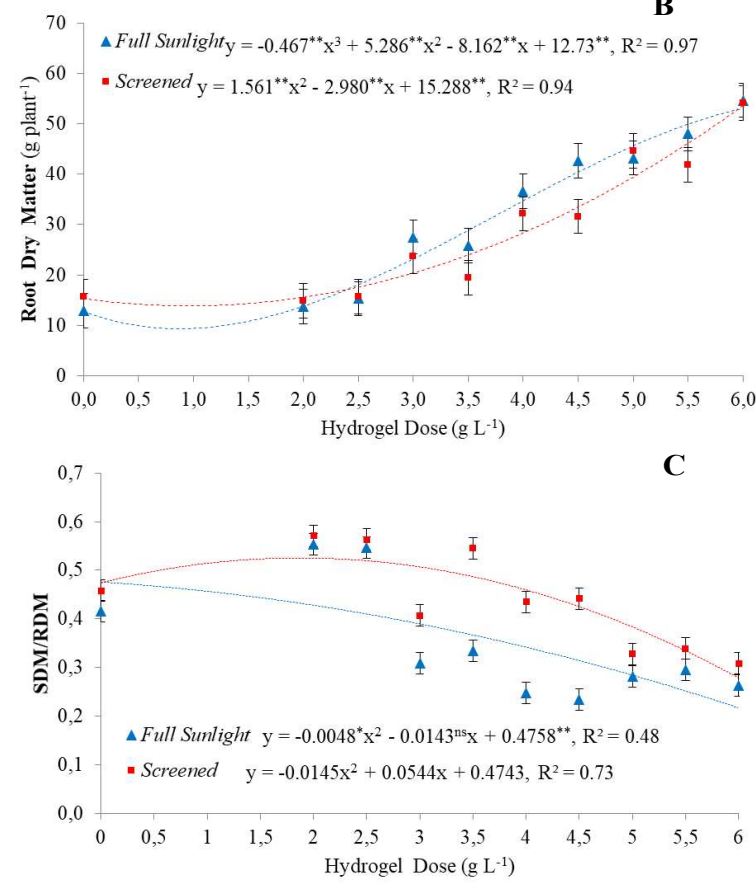

Figure 3 - Shoot dry matter - SDM (A), Root dry matter - RDM (B), and SDM to RDM ratio (C), in Enterolobium contortisilliquum (Vell.) Morong grown in soil with added doses of hydrogel and in different light environments (full sun and shaded).

Figura 3 - Matéria seca de caule-SDM (A), Matéria seca de raízes $-R D M(B)$ e Relação $S D M / R D M(C)$ em Enterolobium contortisilliquum (Vell.) Morong cultivado em solo com doses de hydrogel e com diferentes ambientes de luminosidade (pleno sol e telado).

shaded area. It was also found that starting with the dose of $5 \mathrm{~g}$ hydrogel $\mathrm{L}^{-1}$, differences in the SDM to $\mathrm{RDM}$ ratio decreased between plants in the shaded area and those in full sun.

Root length did not differ between the levels of luminosity, ranging from 15.8 to $19.75 \mathrm{~cm}$ (Figure 4A).

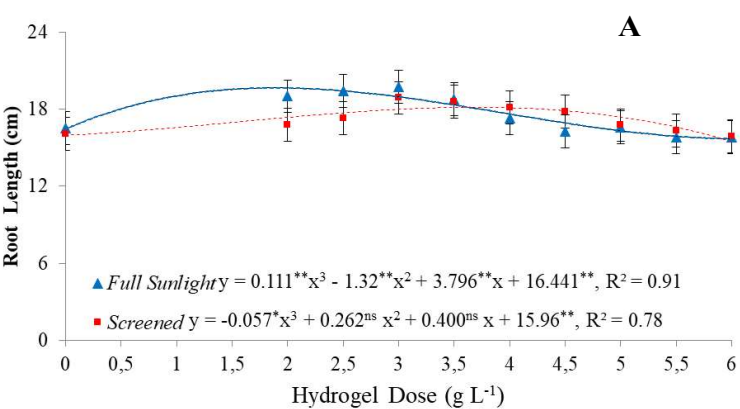

B

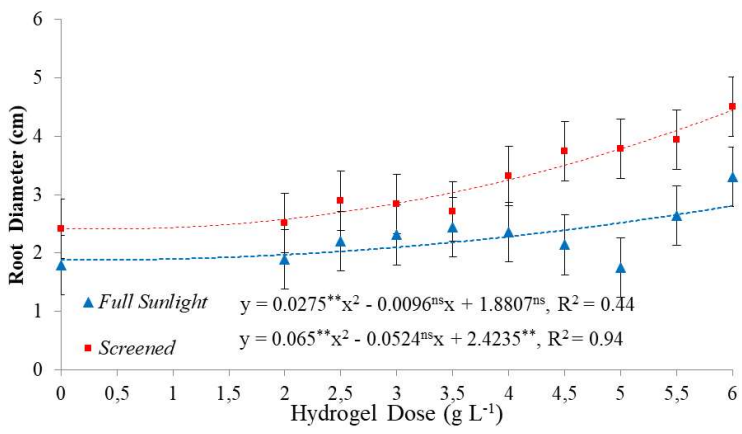

Figure 4 - Root length - RL (A) and Root diameter - RD (B) in Enterolobium contortisilliquum (Vell.) Morong grown in soil with added doses of hydrogel and in different light environments (full sun and shaded)

Figura 4-Comprimento de raízes - $R L(S)$ e Diâmetro de raizes - RD (B) em Enterolobium contortisilliquum (Vell.) Morong cultivado em solo com doses de hydrogel e com diferentes ambientes de luminosidade (pleno sol e telado).

From the dose of $2.0 \mathrm{~g}$ hydrogel $\mathrm{L}^{-1}$ there was increase in root length, with a later reduction at the dose of $3.5 \mathrm{~g} \mathrm{~L}^{-1}$ at both levels of luminosity. The coefficient of determination was low for the root diameter of the seedlings in full sun (Figure 4B). However, there was a difference in root diameter as a function of luminosity, with lower values for the plants in full sun (from 1.75 to $3.31 \mathrm{~cm}$ ), and higher values for the shaded plants (from 2.42 to $4.51 \mathrm{~cm}$ ) (Figure 4B). In the shaded environment, the dose of $2.5 \mathrm{~g}$ hydrogel $\mathrm{L}^{-1}$ promoted an increase in root diameter (Figure 4B).

\section{DISCUSSION}

Coefficients of determination close to 1.0 show that the regression equations were adequate in describing the variations of most of the attributes under evaluation in response to the doses of hydrogel. The height of the seedlings in full sun increased significantly with 
a lower dose $\left(3.5 \mathrm{~g} \mathrm{~L}^{-1}\right)$ than seen for the shaded seedlings $\left(5.0 \mathrm{~g} \mathrm{~L}^{-1}\right)$. This means that in full sun, when water is more limited, a smaller dose of hydrogel favours seedling development in Enterolobium contortisilliquum (Vell.) Morong. The greater water limitation for the seedlings in full sun can be explained by the greater evapotranspiration than occurs under shaded conditions, with interception of the solar radiation and a reduction in the energy available for evapotranspiration (Feng et al., 2014).

With the $3.0 \mathrm{~g} \mathrm{~L}^{-1}$ dose of hydrogel, the shaded seedlings displayed greater height than those developed in full sun. The greater height of the plants grown in the shaded environment can be explained by the increase in stem length which enables the plants to capture more light, as previously seen in Enterolobium contortisilliquum (Vell.) Morong (Melo et al., 2008; Lima et al., 2010), a pioneer and heliophilic species (Lorenzi, 1998; Melo et al., 2008). Moraes Neto et al. (2000) state that the greater heights and diameters in tree species developed in the shade may be due to plant adaptation. These plants grow more quickly to escape the light deficit, as they are not able to tolerate low light intensities by adjusting their metabolic rate.

Stem diameter did not differ between seedlings, whether developed in full sun or in the shaded environment, for most of the doses of hydrogel under evaluation. In a study by Melo et al. (2008) with seedlings of Enterolobium contortisilliquum (Vell.) Morong, a reduction in stem diameter was seen with shading. According to those authors, shading reduces the growth regulators and the rate of photosynthesis, thereby reducing the stem diameter of the seedlings.

Lower values for the ratio between height and stem diameter are associated with more-vigorous plants, since higher values indicate etiolation (Marana et al., 2008). The doses of 0 and $2 \mathrm{~g}$ hydrogel $\mathrm{L}^{-1}$ were therefore more favourable to the seedlings developed in full sun. In the shaded environment, the dose of $3 \mathrm{~g} \mathrm{~L}^{-1}$ gave lower values for the ratio between height and stem diameter. However, in the shaded environment this ratio had a low coefficient of determination, indicating that the response was more influenced by shading than by the dose of hydrogel.

Despite the $2.0 \mathrm{~g} \mathrm{~L}^{-1}$ dose of hydrogel having no effect increasing height or diameter in Enterolobium contortisilliquum (Vell.) Morong, this dose gave an increase in shoot dry matter for seedlings grown in full sun. Without the application of hydrogel (dose of $0 \mathrm{~g} \mathrm{~L}^{-1}$ ), the shoot dry weight of the seedlings developed in full sun was significantly lower than that seen in the shaded seedlings.

The results discussed in the previous paragraph indicate that the $2.0 \mathrm{~g} \mathrm{~L}^{-1}$ dose of hydrogel had a positive effect, mitigating the water deficit to allow the seedlings to invest more in the production of shoot biomass when developed in full sun. Under conditions of water deficit, there is less production of shoot biomass, and greater production of root biomass (Lloret et al., 1999). With the reduction in water deficit promoted by the hydrogel, it was expected that the seedlings produce more shoot than root biomass.

However, other attributes evaluated in this study serve as an indication that the seedlings grown in full sun faced water restrictions, even with the addition of hydrogel. Root dry weight and root length in Enterolobium contortisilliquum (Vell.) Morong were greater in full sun. The greater root growth of the seedlings in full sun, reducing the values for the ratio of shoot dry weight to root dry weight, can be considered a strategy to favour plant development when under water stress (Espinoza et al., 2014).

Due to the low coefficient of determination of the SDM to RDM ratio, it is not possible to indicate the dose that might have influenced this attribute in full sun. However, the SDM to RDM ratio was lower in the seedlings developed in full sun for most of the hydrogel doses under evaluation. In studies by Dantas (2014) and Melo et al. (2008), plants of Enterolobium contortisilliquum (Vell.) Morong and Erythrina velutina Marth submitted to water stress also presented a lower SDM to RDM ratio, which demonstrates that plants which are under more stress, tend to invest in root production in order to increase the efficiency of water absorption. As already discussed in this study, the evapotranspiration must have been more intense in full sun, compromising water availability, even with the addition of the hydrogel.

Regarding seedling development under the conditions of shading or full sun, the values for height, stem diameter, shoot dry weight and shoot/root ratio were higher under shading. The study by Lima et al. (2010) also found greater growth in seedlings of Enterolobium contortisilliquum (Vell.) Morong under shaded conditions. On the other hand, Melo et al. (2008)

Revista Árvore. 2018;42(1):e420112

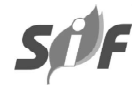


found that for five levels of shading, the highest quality plants of Enterolobium contortisilliquum (Vell.) Morong developed both in full sun and under $20 \%$ shading; whereas, Souza et al. (2017) found greater growth in seedlings of this species under full sun.

Enterolobium contortisilliquum (Vell.) Morong is considered a pioneer species (Lorenzi, 1998; Melo et al., 2008; Lima et al., 2010), and its low survival under shaded conditions was highlighted in the study by Melo et al. (2008). Because it is a heliophite species (Lorenzi, 1998), the plants need larger amounts of solar radiation for their development. However, as seen by Lima et al. (2010), there are certain conditions that can help seedlings of the species to develop better under shaded conditions.

Greater development of the plants under shaded conditions, as seen in the present study, is related to physiological and environmental characteristics. Enterolobium contortisilliquum (Vell.) Morong has more chlorophyll $a$ and more total chlorophyll when grown in a shaded environment (Souza et al., 2017). Chlorophyll $a$ absorbs light at wavelengths greater than $680 \mathrm{~nm}$, while chlorophyll $b$ absorbs light at shorter wavelengths (Rabinowitch and Govindjee, 1965). Therefore, under the conditions of this study, the occurrence of the more-favourable wavelength for chlorophyll $a$, and the greater amount of this type of chlorophyll in the plants that developed in the shaded environment, probably resulted in greater plant growth.

Values for root length were similar to those found by Gonçalves et al. (2013) for substrates that were considered by those authors to be of better quality. In the present study, the fact that the same substrate was used justifies the similarity in root length for the two light conditions. The increase in root length with the dose of $2 \mathrm{~g}$ hydrogel $\mathrm{L}^{-1}$ indicates that this dose favoured the production of root biomass. The reduction in root length seen with the dose of $3.5 \mathrm{~g}$ hydrogel $\mathrm{L}^{-1}$ is an indication that expansion of the hydrogel limits root development. As the hydrogel can absorb water hundreds of times its own dry weight (Hennink and van Nostrum, 2012), this promotes its expansion in the soil.

Root diameter was little influenced by the dose of hydrogel, but was smaller in the seedlings in full sun than in those that developed in the shaded environment. For plants developed in full sun, root dry weight was greater at several doses of hydrogel, and it was assumed that the reduction in diameter was caused more by a loss of water from the roots than by a reduction in dry-matter biomass.

\section{CONCLUSION}

The dose of $2 \mathrm{~g}$ hydrogel $\mathrm{L}^{-1}$ promoted improvements in the growth attributes of seedlings of Enterolobium contortisilliquum (Vell.) Morong developed in full sun. For seedlings grown in the shaded environment, the growth attributes improved with the dose of $3.5 \mathrm{~g}$ hydrogel $\mathrm{L}^{-1}$. Although a response by the species to the doses of hydrogel was found, the benefits of the polymer were not evident under the conditions of the present study.

\section{ACKNOWLEDGEMENTS}

The authors wish to thank the Federal Institute of Education (Maracanaú Campus) for the leave of absence granted to the first author to pursue his Doctorate, and for providing the infrastructure for the experiment. The authors would also like to thank the undergraduate students for their support with the experimental activities, the Brazilian Confederation of Agriculture and Livestock (CNA), and the Brazilian Agricultural Research Corporation (Embrapa) for funding this research through the Biome Project.

\section{REFERENCES}

Araújo AP, Paiva Sobrinho S. Germinação e produção de mudas de tamboril (Enterolobium contortisiliquum (Vell.) Morong) em diferentes substratos. Revista Árvore. 2011;35(3):581-8.

Barreto SSB, Ferreira RA. Aspectos morfológicos de frutos, sementes, plântulas e mudas de Leguminosae Mimosoideae: Anadenanthera colubrina (Vellozo) Brenan e Enterolobium contortisiliquum (Vellozo) Morong. Revista Brasileira de Sementes. 2011;33:223-32.

Dantas SG. Crescimento inicial e morfologia foliar em plantas de Enterolobium contortisiliquum (Vell.) Morong. e Erythrina velutina Mart. ex Benth, sob estresse hídrico [dissertação]. Natal: Universidade Federal do Rio Grande do Norte; 2014.

Du Preez CC, van Huyssteen CW, Mnkeni PNS. Land use and soil organic matter in South Africa 
2: A review on the influence of arable crop production. The South African Journal of Science. 2011;107:35-42.

Espinoza SE, Martínez VA, Magni CR, Ivkovic M, Santelices RE, Guerra FP. et al. Genetic control of growth, biomass allocation, and survival under drought stress in Pinus radiata D. Don seedlings. Tree Genetics \& Genomes. 2014;10:1045-54.

Fajardo L Rodriguez, J. P, González, V, BriceñoLinares, J. M. Restoration of a degraded tropical dry forest in Macanao, Venezuela. Journal of Arid Environments.2013;88:236-43.

Feng Y, Qiu GY, Zhang Q. Determination of canopy-shadow-affected area in sparse steppes and its effect on evaporation and evapotranspiration. Ecohidrology. 2014;7:1589-603.

Ferreira DF. SISVAR: a computer statistical analysis system. Ciência e Agrotecnologia.2011;35:1039-42.

Figueiredo JM, Araújo JM, Pereira ON, Bakke IA, Bakke OA. Revegetation of degraded caatinga sites. Journal of Tropical Forest Science. 2012;24(3):332-43.

Fundação Cearense de Meteorologia e Recursos Hídricos - Funceme; Instituto de Pesquisa e Estratégia Econômica do Ceará - Ipece. Perfil básico municipal. Maracanaú: 2014.

Gonçalves FG, Alexandre RS, Silva AG, Lemes EQ, Rocha AP, Ribeiro MPA. Emergência e qualidade de mudas de Enterolobium contortisiliquum (Vell.) Morong (Favaceae) em diferentes substratos. Revista Árvore. 2013;37(6):1125-33.

Hennink WE, van Nostrum CF. Novel crosslinking methods to design hydrogels. Advanced Drug Delivery Reviews. 2012;64:223-36.

Koupai JA, Sohrab F, Swarbrick G. Evaluation of hydrogel application on soil water retention characteristics. Journal of Plant Nutrition. 2008;31:317-31.

Lima ALS, Zanella F, Castro LDM. Crescimento de Hymenaea courbaril L. var. stilbocarpa (Hayne) Lee et Lang. e Enterolobium contortisiliquum (Vell.) Morong (Leguminosae) sob diferentes níveis de sombreamento. Acta Amazonica. 2010;40(1):43-8.

Lloret F, Casanovas C, Peñuelas J. Seedling survival of mediterranean shrubland species in relation to root:shoot ratio, seed size and water and nitrogen use. Functional Ecology.1999;13:210-6.

Lorenzi H. Árvores brasileiras: Manual de identificação e cultura de plantas arbóreas nativas e cultivo de plantas arbóreas nativas do Brasil. 2a . ed. Nova Odessa: Plantarum; 1998. v.1.

Marana JP, Miglioranzan EPF, Kainumam RH. Índices de qualidade e crescimento de mudas de café produzidas em tubetes. Ciência Rural. 2008;38:39-45.

Melo RR, Cunha MCL, Rodolfo Júnior, F. Crescimento inicial de mudas de Enterolobium contortisiliquum (Vell.) Morong. sob diferentes níveis de luminosidade. Revista Brasileira de Ciências Agrárias. 2008;3(2):138-44.

Mendonça TG, Urbano VR, Peres JG, Souza CF. Hidrogel como alternativa no aumento da capacidade de armazenamento de água no solo. Water Resources and Irrigation Management. 2013;2:87-92.

Moraes Neto SP, Gonçalves JLM, Takaki M, Gonçalves JC. Crescimento de mudas de algumas espécies arbóreas que ocorrem na mata atlântica em função do nível de luminosidade. Revista Árvore. 2000;24:35-45.

Noffs PS, Galli LF, Gonçalves JC. Recuperação de áreas degradadas da mata atlântica: Uma experiência da CESP - Companhia Energética de São Paulo. São Paulo: Conselho Nacional da Reserva da Biosfera da Mata Atlântica; 2000.

Ochoa PA, Fries A, Mejía D, Burneo JI, RuízSinoga JD, Cerdà A. Effects of climate, land cover and topography on soil erosion risk in a semiarid basin of the Andes. Catena. 2016;140:31-42.

Rabinowitch EI, Govindje E. The role of Chlorophyll in photosynthesis. Scientific American. 1965;213:74-83.

Revista Árvore. 2018;42(1):e420112 
Souza AJJ, Guimarães RJ, Colombo A, Sant'ana JAV. Quantitative analysis of growth in coffee plants cultivated with a water-retaining polymer in na irrigated system. Revista Ciência Agronômica. 2016;47:162-71.

Souza JP, Melo MJ, Halfeld AD, Reis J. Shading effects on leaf life span and functional traits in the widespread species Enterolobium contortisiliquum (Vell.) Morong. Acta Scientiarum. 2017;39:113-22.
Torres D, Nectalí R, Yendis H, Florentino A, Zamora F. Cambios en algunas propiedades químicas del suelo según el uso de la tierra en el sector el Cebollal, Estado Falcon, Venezuela. Bioagro. 2006;18(2):123-8.

Vicente MR, Mendes AA, Silva F, Oliveira FR, Mota Júnior MG, Lima VOB. Uso de gel hidrorretentor associado à irrigação no plantio do eucalipto. Revista Brasileira de Agricultura Irrigada. 2015;9(5):344-9. 